\title{
Anaplasma phagocytophilum direct detection and exposure evidence in equines from two breeding farms from Minas Gerais State, Brazil
}

\author{
Detecção direta e evidência da exposição a Anaplasma \\ phagocytophilum em equinos de dois haras em Minas Gerais, Brasil \\ Luan Gavião Prado ${ }^{*}$, Maristela Silveira Palhares ${ }^{1}$, Camila Valgas e Bastos ${ }^{2}$, Júlia Angélica \\ Gonçalves da Silveira ${ }^{3}$, Álvaro Augusto Ramos Ribeiro², Ana Luísa Soares de Miranda², \\ Vinícius Monteiro Bezerra², Múcio Flávio Barbosa Ribeiro²
}

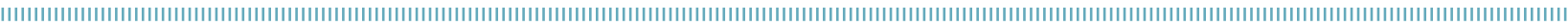

\begin{abstract}
Equine granulocytic anaplasmosis is caused by Anaplasma phagocytophilum, a gram negative, obligatory intracellular bacterium, member of Anaplasmataceae family, included in the Rickettsiales order. Little is known about the disease, transmission dynamics, genetic diversity and prevalence in Minas Gerais state, Brazil. This work aimed to do a serosurvey using indirect immunofluorescent assay (IFA) test and evaluation of buffy coat smears, and nested polymerase chain reaction (PCR) as diagnostic methods, to determine the disease situation in horses from two manga-larga marchador breeding farms located in the municipalities of Ataléia e São Vicente de Minas, in Minas Gerais state. It was found that $76 \%(131 / 172)$ of the animals were considered reactive for IFA test, and the total of $12.8 \%$ was positive at buffy coat smears analysis. At PCR analysis, it was found $1.94 \%$ of the samples positive to the infection. Those samples were sequenced and showed $96 \%$ of similarity to A. phagocytophilum from a Ixodes ricinus tick. There is a high frequency of animals with the evidence of contact to $A$. phagocytophilum on the two evaluated properties in this study, which was proved by positiveness in PCR analysis. New researches must be carried out to better understand the epidemiologic and clinical dynamic of the disease in the state of Minas Gerais.
\end{abstract}

KEYWORDS: Horses; serology; immunofluorescence; nested polymerase chain reaction; Anaplasmataceae.
RESUMO: A anaplasmose granulocítica equina é causada por uma bactéria gram-negativa, intracelular obrigatória, membro da família Anaplasmataceae, incluída na ordem Rickettsiales e denominada de Anaplasma phagocytophilum. Pouco se sabe sobre a doença, sua dinâmica de transmissáo, diversidade genética e prevalência em Minas Gerais, Brasil. Este trabalho teve por objetivo realizar o levantamento sorológico utilizando a reação de imunofluorescência indireta, avaliação direta de capa leucocitária e nested reaçáo em cadeia da polimerase (PCR) como métodos diagnósticos, a fim de avaliar a situaçáo da doença em dois haras de criação de cavalos manga-larga marchador localizados nas cidades de Ataléia e Sáo Vicente de Minas, no estado de Minas Gerais. Foi encontrada prevalência de 76\% (131/172) de animais reativos para a reação de imunofluorescência indireta, quando todos os animais das duas propriedades e das duas coletas foram agrupados, e 12,8\% dos animais foram positivos na avaliação da capa leucocitária. A reação de imunofluorescência indireta detectou $1,94 \%$ das amostras como positivas para o agente. Essas amostras foram submetidas ao sequenciamento de nucleotídeos, e foi observada similaridade de $96 \%$ com $A$. phagocytophilum proveniente de carrapatos Ixodes ricinus. Existe alta prevalência de animais positivos para a infecção por $A$. phagocytophilum, o que foi provado pela positividade dos animais à PCR. Novas pesquisas devem ser conduzidas a fim de entender a dinâmica epidemiológica e clínica da doença no estado de Minas Gerais.

PALAVRAS-CHAVE: equinos; sorologia; imunofluorescência; nested reação em cadeia da polimerase; Anaplasmataceae. 


\section{INTRODUCTION}

Equine granulocytic anaplasmosis (EGA) is caused by an obligatory intracellular bacterium known as Anaplasma phagocytophilum. Based on molecular analysis, the agent of the Human Granulocytic Ehrlichiosis, Ehrlichia equi, and Ehrlichia phagocytophila were regrouped to an only species: Anaplasma phagocytophilum (DUMLER et al., 2001; VON LOEWENICH et al., 2003).

First description of equine infection was in 1969, in California State, United States of America (GRIBBLE, 1696; STANNARD et al., 1969), and in human beings in 1994, also in the United States (BAKKEN et al., 1994). Cases of the infection in equines were described in Germany (VON LOEWENICH et al., 2003), and serological evidences of the infection were described in Brazil (SALVAGNI et al., 2010), Denmark (HANSEN et al., 2010), Spain (DE LA FUENTE et al., 2005) and Switzerland (PUSTERLA et al., 1999).

In Brazil, EGA is considered an emerging disease, and little is known about its epidemiology, pathology and transmission. In a clinical and serological survey in central-west region of Brazil, SALVAGNI et al. (2010) found prevalence of $65 \%$ of positiveness in enzyme-linked immunosorbent assay (ELISA) test. Despite that, no samples from those horses were considered positive by evaluation of the buffy coat smear or nested PCR (nPCR).

The disease is characterized by hyperthermia, anorexia, depression, limb edema, ataxia and low mortality. Inclusions body in neutrophils, leucopenia, thrombocytopenia and mild anemia are the most prevalent hematological alterations (GRIBBLE, 1969; SALVAGNI et al., 2010).

EGA diagnose can be performed by clinical signs interpretation and intracytoplasmic inclusions on neutrophils (STANNARD et al., 1969; DE LA FUENTE et al., 2005; SALVAGNI et al., 2010). Serologic methods like ELISA, indirect immunofluorescent assay (IFA) test, and polymerase chain reaction (PCR) - conventional and real time - are used as diagnostic methods (DE LA FUENTE et al., 2005; HANSEN et al., 2010; SALVAGNI et al., 2010). IFA test is considered a good diagnostic test if some care are taken to avoid cross-reaction false negative (ZIMMERMAN; CRISMAN, 2008).

This paper aimed to make a serosurvey using IFA test, buffy coat smears evaluation and nPCR as diagnostic methods, with the purpose of evaluating the epidemiologic situation of the disease in two manga-larga marchador breeding farms at the municipalities of Ataléia and São Vicente de Minas, Minas Gerais state, Brazil.

\section{MATERIAL AND METHODS}

This experiment was conducted accordingly with ethical concepts and precepts after approval at Comissão de Ética no Uso de Animais (CEUA) of Federal University of Minas Gerais (Universidade Federal de Minas Gerais - UFMG), under protocol no. 167/2013. The use of all the animals' samples was approved by their owners, that signed a consent term.

\section{Collection sites and periods}

The experiment was performed during two distinct seasons (rainy and dry) in two properties located in Ataléia and São Vicente de Minas, in north-west and south regions of Minas Gerais. Both have well defined seasons: April to September, dry season; and October to March, rainy season.

São Vicente de Minas is located at south region of Minas Gerais state and belongs to Andrelândia microregion. City seat is at the altitude of 962 meters and its geographic position is $21^{\circ} 42^{\prime} 46^{\prime \prime}$ south latitude and $44^{\circ} 26^{\prime} 38^{\prime \prime}$ west latitude. Ataléia is located in Minas Gerais' north-west region and belongs to the microregion of Teófilo Otoni. City seat is at the altitude of 264 meters and its geographic position is $18^{\circ} 02^{\prime} 38^{\prime \prime}$ south latitude and $41^{\circ} 06^{\prime} 36^{\prime \prime}$ west latitude. Both properties, located in the referred cities, will be mentioned as property 1 and property 2 along the paper.

\section{Sample calculation and studied population}

Samples collection was calculated accordingly with the Pan American Zoonoses Center formula (Equation 1) (CEPANZO, 1973):

$\mathrm{n}=\mathrm{p} \times(100-\mathrm{p}) \mathrm{z}^{2} /(\mathrm{d} \times \mathrm{p} / 100)^{2}$

In which:

$\mathrm{n}=$ number of individuals to study (number of samples);

$\mathrm{p}=$ expected prevalence;

$\mathrm{z}=95 \%$ confidence degree.

$\mathrm{d}=$ expected error.

Considering the expected prevalence (p) of $64.9 \%$ (GAVIÃO PRADO et al., 2011), the expected error (d) of $15 \%$ and the $95 \%$ confidence degree $(\mathrm{z})$ of 1.96 , at least 92 samples should be used.

Eighty-four animals were studied at property $1: 40$ at the first visit, and 44 at the second one. At property 2, 88 animals were studied: 43 at the first visit, and 45 at the second one. Both properties are manga-larga marchador breeding farms. Distribution accordingly with sex is demonstrated at Table 1 . Because they

Table 1. Animal distribution accordingly with property, season of the year and sex.

\begin{tabular}{lcccc} 
& \multicolumn{2}{c}{ Property 1} & \multicolumn{2}{c}{ Property 2} \\
\cline { 2 - 5 } Sex & $\begin{array}{c}\text { Summer } \\
(\%)\end{array}$ & $\begin{array}{c}\text { Winter } \\
(\%)\end{array}$ & $\begin{array}{c}\text { Summer } \\
(\%)\end{array}$ & $\begin{array}{c}\text { Winter } \\
(\%)\end{array}$ \\
\hline Female & 52.50 & 52.27 & 86.05 & 68.89 \\
\hline Male & 22.50 & 29.55 & 6.98 & 13.33 \\
\hline Castrated male & 25.00 & 18.18 & 6.98 & 17.78 \\
\hline
\end{tabular}


were farms designated to breeding, buying and selling animals, it was not possible to precise how many animals and which of them were evaluated at the first and, again, at the second visit.

\section{Material collection, processing and evaluation}

Blood collection was made by jugular venipuncture, after contention and local antisepsis with $70 \%$ alcohol. Two tubes were collected, one without anticoagulants and other with ethylenediamine tetraacetic acid (EDTA).

EDTA tube blood was used to make buffy coat smears. With the help of a microhematocrit centrifuge, microtubes were centrifuged, and buffy coats were removed after breaking the microtubes. Buffy coat smears were made in glass microscope slides. Then, they were colored using modified Romanowski method and analyzed using light microscopy, under $100 \times$ magnification, to look for intracytoplasmic inclusions of $A$. phagocytophilum in neutrophils. The sample was considered positive if no inclusion had been seen, independently of the percentage of infected cells.

After clot retraction, tubes without anticoagulants were centrifuged at 3,000 rpm, for 5 minutes. Serum obtained was frozen at $-20^{\circ} \mathrm{C}$, in six $0.5 \mathrm{~mL}$ aliquots.

IFA tests slides, with 12 wells, were previously prepared at Protozoology Laboratory of the Institute of Biological Sciences of UFMG., with an Ixodes scapularis tick cell line (IDE8) kept $A$. phagocytophilum antigen and fixed using cold acetone. Antigens fixation and fabrication technique was adapted from AGUIAR et al. (2007).

After technique standardization, serum samples were diluted at 1:160 proportions in buffered phosphate saline 1× (PBS 1x), that was considered the cut off for the analyses, and, then, pipetted to slides wells. Serum reacted with slides antigens for 30 minutes, in moist chamber, at $37^{\circ} \mathrm{C}$. After that, slides were washed three times, first and second times with PBS $1 \times$, and the last one with distilled water. After each lavage, slides were submersed in PBS $1 \times$ and distilled water, respectively, for 3 minutes.

Slides were dried at room temperature. Afterwards, it was pipetted the fluorescein isothiocyanate (FITC) Anti-horse IgG conjugate (whole molecule) to fluorescein isothiocyanate (FITC) antibody produced in rabbit (Sigma-Aldrich, St. Louis, Missouri, United States), previously diluted in Evans blue, at 1:160 proportion. First reaction was repeated, as described before. At last, slides were covered with alkaline glycerin and cover slip and evaluated at an epifluorescence microscope. Samples were considered positive if fluorescence were present at 1:160 dilution, as it was the cut off. As positive control, it was used an IFA and PCR positive serum sample, and as negative control it was used PBS 1×. After trial, positive samples were diluted again at 1:320, 1:640 and 1:1,280 proportions.

Among all the 172 used samples for serological and evaluation of buffy coat smears, 103 were randomly chosen: 84 from property 1 ( 40 from the first collection, and 44 from the second one); and 19 from property 2 (nine from the first collection; and 10 from the second one). Moreover, they were used for molecular analyses using the nPCR technique, as recommended by SILAGHI (2012).

\section{Statistical analyses}

Data was recorded using Microsoft Excel and analyzed by statistical program Statistical Analysis System (SAS, 2003).

IFA tests results were used to $A$. phagocytophilum seroprevalence calculi. Non-parametric data were submitted to $\log (x+1)$ transformation and percentages to $\arcsin \sqrt{\mathrm{x}}$ transformation. Even though, data was still non-parametric. So, mean values were compared by Wilcoxon test (two means) or by Kruskal-Wallis test (three or more means). Proportional variables were compared by $\chi^{2}$ test.

Prevalence was calculated by the formula (Equation 2):

Number of total cases / total studied population

And the cumulative incidence was calculated by the formula (Equation 3):

New cases / initial population at infection risk

\section{RESULTS AND DISCUSSION}

In the visits, ticks parasitizing horses were found. They were collected, and a tick pool was made from each property, during each visit, and infestation was properly documented for each animal. Frequency of infested animal accordingly with the period of the year and property is summarized at Table 2 .

At property 1, in summer, from all the five infested horses, nine adult females and two ingurgitate nymph of Dermacentor (Anocentor) nitens were identified. In the winter, 12 Dermacentor (Anocentor) nitens ingurgitate females, four males and two ingurgitate females of Rhipicephalus (Boophilus) microplus and one Amblyomma cajennense male were seen.

At property 2, in summer, 23 animals were found parasitized, and it was possible to identify six ingurgitated and three non-ingurgitated Amblyomma cajennense females, one Rhipicephalus (Boophilus) microplus ingurgitated female and two ingurgitated

Table 2. Frequency distribution accordingly with reactiveness to indirect immunofluorescent assay (IFA) test at cut-off titer (1:160), property and season of the year, in an Anaplasma phagocytophilum serosurvey in two regions of Minas Gerais state, Brazil.

\begin{tabular}{lcccc} 
& \multicolumn{2}{c}{ Property 1} & \multicolumn{2}{c}{ Property 2} \\
\cline { 2 - 5 } IFA Test & $\begin{array}{c}\text { Summer } \\
(\%)\end{array}$ & $\begin{array}{c}\text { Winter } \\
(\%)\end{array}$ & $\begin{array}{c}\text { Summer } \\
(\%)\end{array}$ & $\begin{array}{c}\text { Winter } \\
(\%)\end{array}$ \\
\hline Reactive & 62.50 & 77.27 & 88.37 & 75.56 \\
\hline Non-reactive & 37.50 & 22.73 & 11.63 & 24.44 \\
\hline
\end{tabular}


Dermacentor (Anocentor) nitens females. During the winter visit, three adult females and one ingurgitated nymph of Rhipicephalus (Boophilus) microplus and one Dermacentor (Anocentor) nitens ingurgitated adult female (Figs. 1 and 2) were identified.

Both properties had "dirty" pasture with some shrubby vegetation that facilitates ticks maintenance in pasture. In the sun free, humid and optimal temperature, female ticks can do their oviposition, and the environment guarantees protection to the new born larvae (TORRES et al., 2012).

There was significant difference $(\mathrm{p}<0.05)$ between year season and the number of parasitized animals in property 1 : infestation was bigger during the winter season. There was also difference $(\mathrm{p}<0.05)$ between the number of parasitized animals between properties during summer; it was observed that in property 2 there was a larger number of parasitized animals. No strategical control is made in none of the properties to lower the tick number. Control is only made when adult ticks are seen on the horses. This data justifies the occurrence of so many horses presenting ticks during the visit and the difference between properties, since property 1 has a more intense work with horses, making it possible to observe any infestation sooner than in property 2.

Distribution of positive and negative animals at IFA test, accordingly with property and season of the year, is found in Table 3 .

It was found $76.16 \%$ (131/172) of positive animals when all the animals were grouped and analyzed independently of the property and visit. Property 2 had $88.37 \%$ (38/43) of positive animals at IFA test in 1:160 dilution. There was no difference in distribution of positive and negative animals between properties $(\mathrm{p}=0.0531)$. There was no difference $(p>0.05)$ in frequency of positive and negative animals between first and second visit in each property.

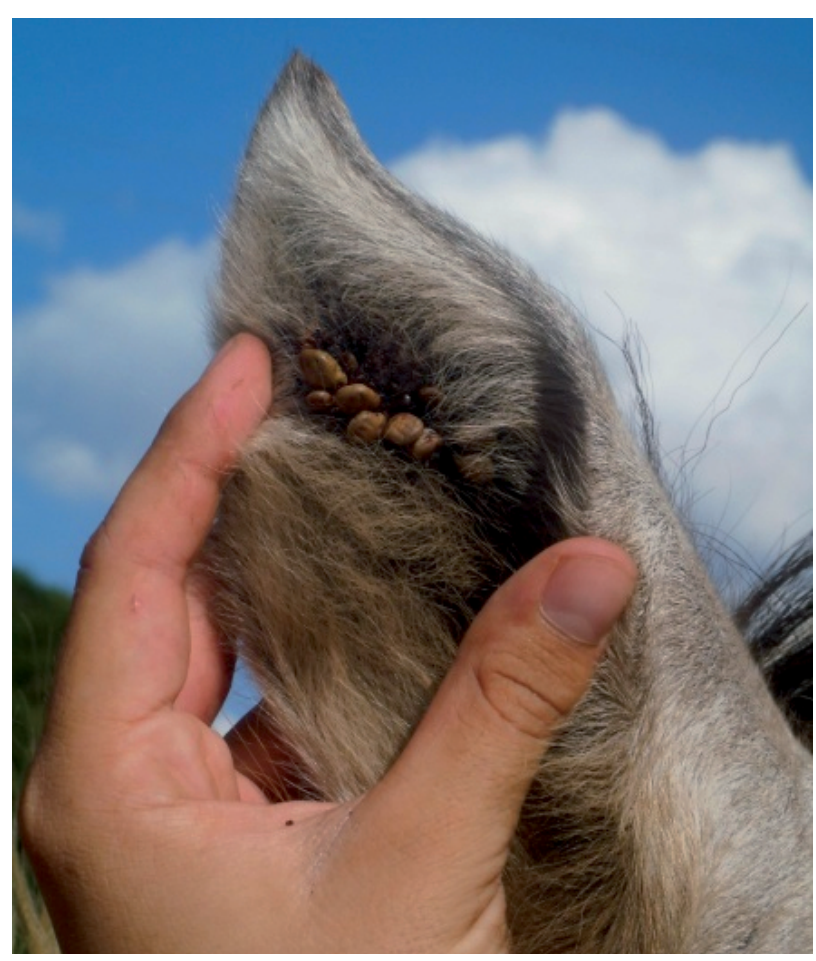

Figure 1. Equine pinna showing ticks' infestation.
Positive samples were diluted, and titration of each animal was studied. One sample from property 1 was lost, not being possible to evaluate. Table 4 shows the distribution of titration of positive IFA test animals, according with property and visit.

The most prevalent titration was 1:320 (43.08\%), when data was analyzed without considering property or season of the year. Property 1, during summer, presented a higher percentage of animals with titers — of 1:1280 (16.67\%) —, but, in total, only

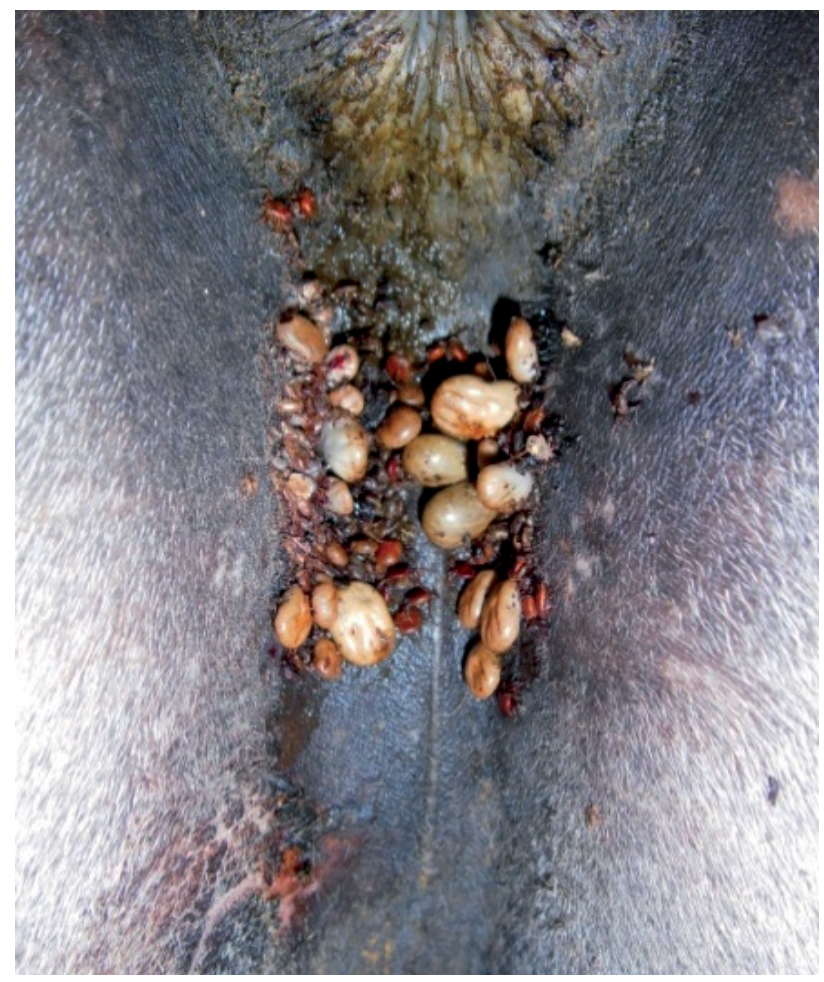

Figure 2. Tick infestation in perianal region in a horse from property 1 .

Table 3. Distribution of tick infested animals in each property, in summer and winter, in Minas Gerais, Brazil.

\begin{tabular}{|c|c|c|}
\hline & \multicolumn{2}{|c|}{ Season of the year $-\%(n)$} \\
\hline & Summer & Winter \\
\hline Property 1 & $12,50(5 / 40)^{\mathrm{Bb}}$ & $36,36(16 / 44)^{\mathrm{a}}$ \\
\hline Property 2 & $53,49(23 / 43)^{A}$ & $35,56(16 / 45)$ \\
\hline
\end{tabular}

*Means followed to different letters, capitals in column and minuscule in lines are statistic difference $(p<0.05)$, by $x^{2}$ test.

Table 4. Frequency distribution of indirect immunofluorescent assay (IFA) test reactive samples, accordingly with property, season of the year and titration, in an Anaplasma phagocytophilum serosurvey, at two regions of Minas Gerais, Brazil.

\begin{tabular}{lcccc}
\multirow{2}{*}{ Titration } & \multicolumn{2}{c}{ Property 1 } & \multicolumn{2}{c}{ Property 2} \\
\cline { 2 - 5 } & $\begin{array}{c}\text { Rain } \\
(\%)\end{array}$ & $\begin{array}{c}\text { Drought } \\
(\%)\end{array}$ & $\begin{array}{c}\text { Rain } \\
(\%)\end{array}$ & $\begin{array}{c}\text { Drought } \\
(\%)\end{array}$ \\
\hline $1: 160$ & 25.00 & 23.53 & 28.95 & 14.71 \\
\hline $1: 320$ & 37.50 & 41.18 & 44.74 & 47.06 \\
\hline $1: 640$ & 20.83 & 32.35 & 13.16 & 23.56 \\
\hline $1: 1280$ & 16.67 & 2.94 & 13.16 & 14.71 \\
\hline
\end{tabular}


$11.54 \%$ of the animals presented that titer. There was no difference between properties and titration, nor between visits and properties.

At property 1, there was no difference between first and second collection, and most of the animals that were positive showed a titer of $1: 160$ or 1:320, which can be explained by the constant presence of the agent in the property.

At property 2, despite the no significance ( $p>0.05)$, there was reduction on the number of positive animals at IFA test. Due to a high flux of animals, ever entering or leaving the property, some animals that were considered positive at the first evaluation could not be there at the second evaluation. And, just arrived animals could have not developed sufficient antibodies to be detected at the test.

From the total of 171 evaluated buffy coat smears, intracytoplasmic inclusions (Fig. 3) that suggested A. phagocytophilum infection in 22 were found. These numbers correspond to half of the percentage found by GAVIÃO PRADO et al. (2011) in a survey performed with $57 \mathrm{draft}$ horses in metropolitan region of Belo Horizonte, Minas Gerais. BUTLER et al. (2008), when evaluated buffy coat smears from six naturally infected horses, found five positive animals. That data is different from values found in this work. Results are summarized in Table 5.

Intracytoplasmic inclusions can be visualized only during the acute phase of the disease. During the collections, no animal showed any signs of EGA. Although, some feverish horses were observed, due to other causes such as strangles and theileriosis. It was expected that animals with intracytoplasmic inclusions showed, at some point, clinical signs of the disease. The absence of clinical signs in these animals could be due to three factors: other concomitants diseases, low pathogenicity of the agent, and protective IgG titers against the agent.

Only two samples (1.94\%) from property 1 (one from collection 1 and one from collection 2 ) were nPCR positive to $A$. phagocytophilum through the msp 4 gene analysis (Fig. 4). After nucleotide sequencing, both samples showed

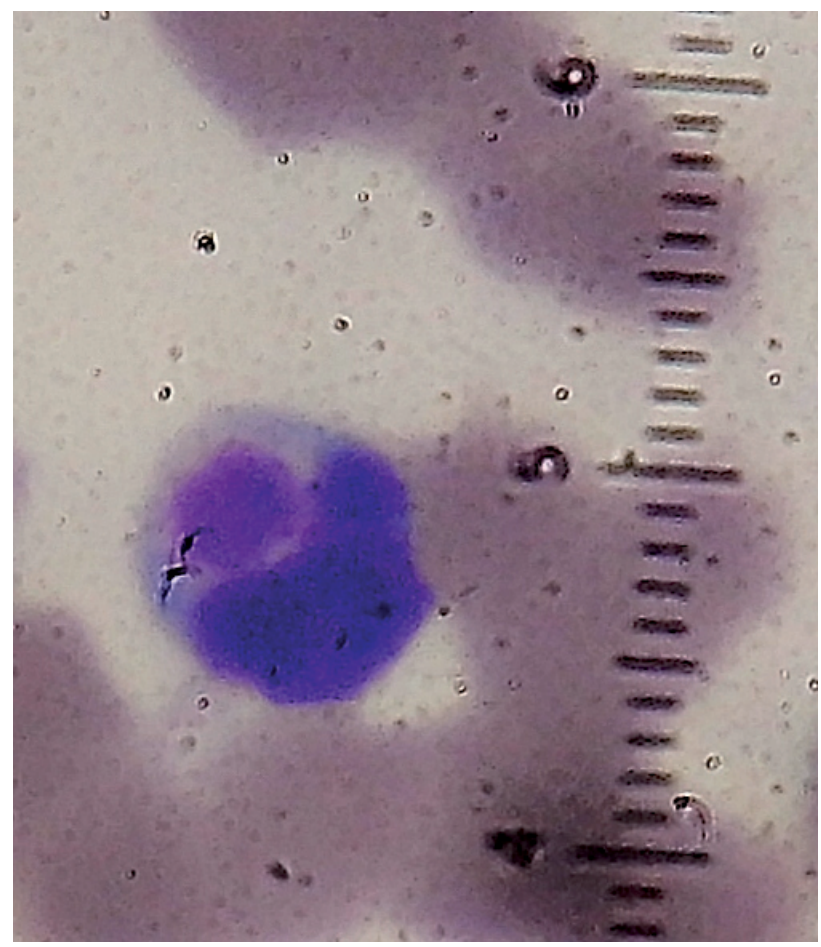

Figure 3. Circulating neutrophil showing intracytoplasmic inclusion, suggestive of Anaplasma phagocytophilum, in 1,000 × magnification.

Table 5. Frequency distribution of the presence of intracytoplasmic inclusions in buffy coat smears, accordingly with properties and season of the year, in an Anaplasma phagocytophilum seroprevalence survey, at two Minas Gerais state's regions, Brazil.

\begin{tabular}{lcccc} 
& \multicolumn{2}{c}{ Property 1} & \multicolumn{2}{c}{ Property 2} \\
\cline { 2 - 5 } Buffy coat & $\begin{array}{c}\text { Summer } \\
(\%)\end{array}$ & $\begin{array}{c}\text { Winter } \\
(\%)\end{array}$ & $\begin{array}{c}\text { Summer } \\
(\%)\end{array}$ & $\begin{array}{c}\text { Winter } \\
(\%)\end{array}$ \\
\hline Positive & 2.50 & 20.93 & 18.60 & 8.89 \\
\hline Negative & 97.50 & 79.07 & 81.40 & 91.11 \\
\hline
\end{tabular}

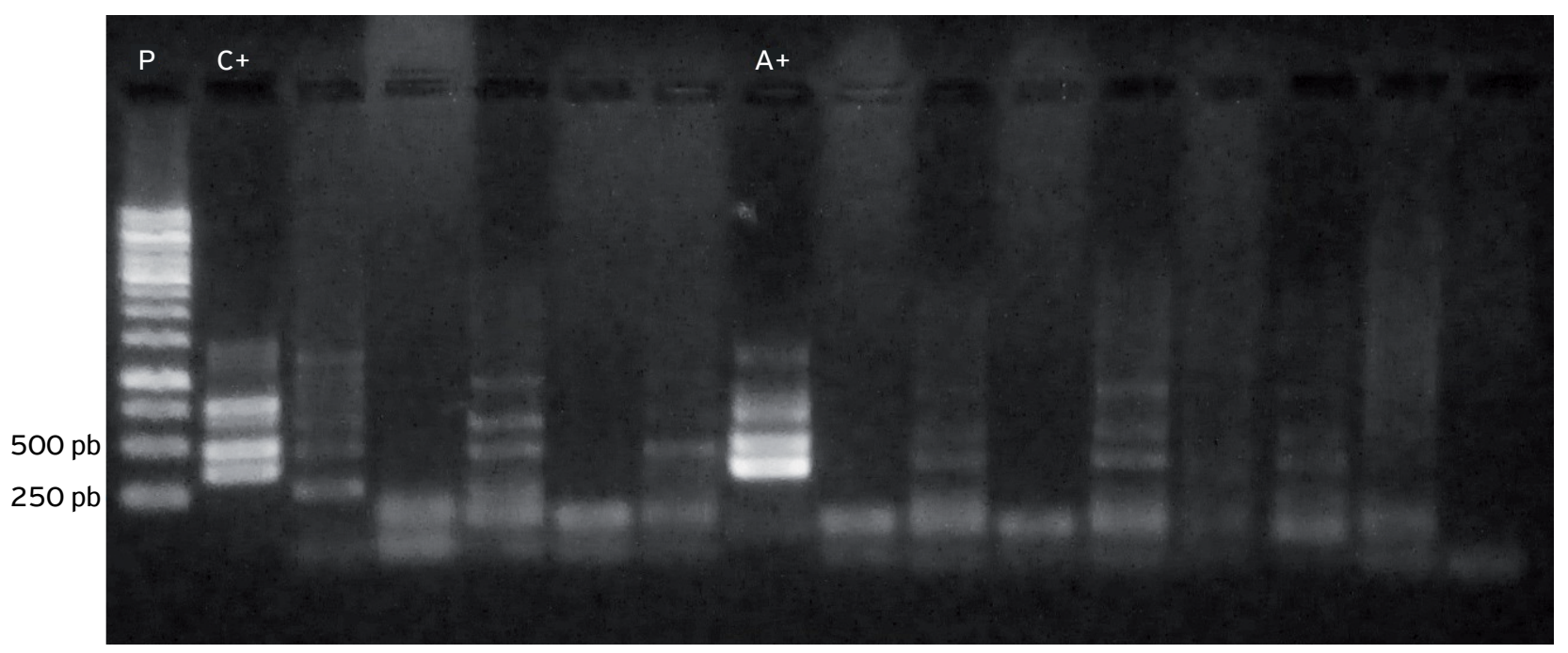

P: Standard, molecular weight $1 \mathrm{~Kb}$; $\mathrm{C}+$ : positive control, obtained after DNA extraction from a cellular cultivation of $A$. phagocytophilum; A+: positive sample; two last gutters as filled with the white reaction from first and second reactions, respectively.

Figure 4. $1 \%$ agarose gel showing a positive sample to Anaplasma phagocytophilum. 
$96 \%$ of similarity to $A$. phagocytophilum from $I$. ricinus tick (access number GenBank: HQ661156.1) (data not published).

\section{CONCLUSION}

There is high prevalence of IFA positive animals to A. phagocytophilum infection in both studied properties in this work. Besides, it was possible to observe that animals that had intracytoplasmic inclusions did not show any signs of the disease.

It is clear, after bibliographic survey and this research, that EGA is still an underdiagnosed disease in all Minas Gerais state and Brazilian territory. New investigations are necessary to understand epidemiological dynamics and clinical features of the disease in Minas Gerais.

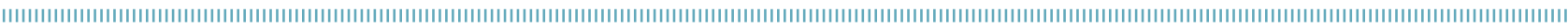
REFERENCES

AGUIAR, D.M.; SAITO, T.B.; HAGIWARA, M.K.; MACHADO, R.Z.; LABUNA, M. B. Diagnóstico sorológico de erliquiose canina com antígeno brasileiro de Ehrlichia canis. Ciência Rural, v.37, n.3, p.796-802, 2007. http://dx.doi.org/10.1590/ S0103-84782007000300030

BAKKEN, J.S.; DUMLER, J.S.; CHEN, S. Human granulocytic ehrlichiosis in the upper midwest United States. A new species emerging? JAMA, v.272, n.3, p.212-218, 1994.

BUTLER, C.M.; NIJHOF, A.M. JONGEJAN, F.; VAN DER KOLK, J.H. Anaplasma phagocytophilum infection in the Netherlands. The Veterinary Record, v.162, n.7, p.216-217, 2008. https://doi. org/10.1136/vr.162.7.216

CENTRO PANAMERICANO DEZOONOSIS. (CEPANZO). Procedimientos para estudios de prevalencia de enfermidades cronicas en el ganado. Ramos Mejia, Buenos Aires, 1973. 35p. (Nota Técnica, 18).

DELAFUENTE, J.; NARANJO, V;:RUIZ-FONS, F.; HÖFLE,U.; FERNANDEZ DEMERA, I,G.; VILLANUA, D.; ALMAZÁN, C.; TORINA, A.; CARACAPPA, S.; KOCAN, K.M.; GORTAZÁR, C. Potencial vertebrate reservoir hosts and invertebrate vectors of Anaplasma marginale and $A$. phagocytophilum in central Spain. Vector-borne and zoonotic diseases, v.5, n.4, p.390-401, 2005. https://doi.org/10.1089/vbz.2005.5.390

DUMLER, J.S.; BARBET, A.F.; BEKKER, C.P.J.; DASCH, G.A.; PALMER, G.H.; RAY, S.C.; RIKIHISA, Y.; RURANGIRWA, F.R. Reorganization of genera in the families Rickettsiaceae and Anaplasmataceae in the order Rickettsiales: unification of some species of Ehrlichia with Anaplasma, Cowdria with Ehrlichia and Ehrlichia with Neorickettsia, descriptions of six new species combinations and designation of Ehrlicia equi and 'HE agent' as subjective synonyms of Ehrlichia phagocytophila. International Journal of Systematic and Evolutionary Microbiology, v.51, p.2145-2165, 2001.

FRANZÉN, P.; ASPAN, A.; EGENVALL, A.; GUNNARSSON, A.; ÁBERG, L.; PRINGLE, J. Acute clinical, hematological, serologic, and polymerase chain reaction findings in horses experimentally infected with a European strain of Anaplasma phagocytophilum. Journal of Veterinary Internal Medicine, v.19, n.2, p.232-239, 2005. https://doi.org/10.1111/j.1939-1676.2005.tb02687.x
GAVIÃO PRADO, L.; BASTOS, C.V.; PALHARES, M.S.; RIBEIRO, M.F.B.; SILVA, R.F.; SOUZA, C.C.; ZWEYGARTH, E.; SILVA FILHO, J.M. Light weight draft equids seroprevalence of Anaplasma phagocytophilum in urban area of Minas Gerais, Brazil. TTP7: Ticks and Tick-borne pathogens International Conference. Zaragoza (Spain), 2011.

GRIBBLE, D.H. Equine Ehrlichiosis. JAVMA, 155: 462-469, 1969.

HANSEN, M.G.B.; CHRISTOFFERSEN, M.; THUESEN, L.R.; PETERSEN, M.R.; BOJESEN, A.M. Seroprevalence of Borrelia burgdorferi sensu lato and Anaplasma phagocytophilum in Danish horses. Acta Veterinaria Scandinavica, v.52, n.3, p.1-6, 2010. https:// doi.org/10.1186/1751-0147-52-3

PUSTERLA, N.; LEUTENEGGER, C.M.; CHAE, J.; LUTZ, H.; KIMSEY, R.B.; DUMLER, J.S.; MADIGAN, J.E. Quantitative evaluation of ehrlichial burden in horses after experimental transmission of Human granulocytic Ehrlichia Agent by intravenous inoculation with infected leucocytes and by infected ticks. Journal of Clinical Microbiology, v.37, n.12, p.4042-4044, 1999.

SILAGHI, C.; SANTOS, A.S.; GOMES, J.; CHRISTOVA, I.; MATEI, I. A.; WALDER, G.; DOMINGOS, A.; BELL-SAKYI, L.; SPRONG, H. VON LOEWENICH, F.D.; OTEO, J.A.; DE LA FUENTE, J.; DUMLER, J.S. Guidelines for the direct detection ofAnaplasma spp. in diagnosis and epidemiological studies. Vector-borne and Zoonotic Diseases, v.17, n.1, p.12-22, 2017. https://doi.org/10.1089/ vbz.2016.1960

STANNARD, A.A.; GRIBBLE. D.H.; SMITH, R.S. Equine Ehrlichiosis: A disease with similarities to tick-borne fever and bovine petechial fever. The Veterinary Record, v.84, n.6, p.149-150, 1969.

VON LOEWENICH, F.D.; STUMPF, G.; BAUMGARTEN, B.U.; RÖLLINGHOFF, M.; DUMLER, J.S.; BOGDAN, C. A case of Equine Granulocytic Ehrlichiosis provides molecular evidence for the presence of pathogenic Anaplasma phagocytophilum (HE agent) in Germany. European Journal of Microbiology and Infectious Disease, v.22, n.5, p.303-305, 2003.

ZIMMERMAN, K.L; CRISMAN, M.V.Diagnostic Equine Serology. Veterinary Clinics of North America: Equine, v.24, n.2, p.31 1-334, 2008. 